\title{
Pengaruh Intensitas Modal, Leverage, Likuiditas Dan Profitabilitas terhadap Agresivitas Pajak
}

\author{
Mufrihatul Awaliyah, Ginanjar Adi Nugraha*, Krisnhoe Sukma Danuta \\ Program Studi Akuntansi Fakultas Ekonomika dan Bisnis, Universitas Wijayakusuma Purwokerto \\ *Corresponding email: ginanjar@unwiku.ac.id
}

\begin{abstract}
Abstrak. Tujuan penelitian ini adalah untuk mengetahui pengaruh variabel independen yaitu; intensitas modal, leverage, likuiditas dan profitabilitas terhadap variable dependen yaitu agresivitas pajak yang diproksikan dengan menggunakan CETR pada perusahaan manufaktur sub sektor food and beverage yang terdaftar di Bursa Efek Indonesia tahun 2015-2019. Jumlah populasi dalam penelitian ini adalah 26 perusahaan dan didapatkan sampel sebesar 13 perusahaan dengan menggunakan metode purposive sampling. Data yang digunakan merupakan data sekunder berupa laporan keuangan yang diperoleh melalui situs www.idx.co.id dan website resmi perusahaan terkait. Metode dalam penelitian ini adalah regresi data panel dengan menggunakan software Eviews. Hasil penelitian menunjukan bahwa intensitas modal dan profitabilitas tidak berpengaruh positif terhadap agresivitas pajak, sedangkan leverage dan likuiditas berpengaruh positif dan signifikan terhadap agresivitas pajak.
\end{abstract}

Kata kunci: Agresivitas Pajak; Intensitas Modal; Leverage; Likuiditas; Profitabilitas.

\begin{abstract}
This purpose of this study was to determine the effect of independent variabels: capital intensity, leverage, liquidity and profitability on the dependent variable namely tax aggressiveness, which is proxied by using CETR in food and beverage sub sector manufacturing companies listed on the Indonesia Stock Exchange in 2015-2019. The population in this study were 26 companies and obtained 13 companies using purposive sampling method. The data used is secondary data in the form of financial reports obtained through the website www.idx.co.id and the official website of the related company. The method in this research is panel data regression using Eviews software. The results showed that the capital intensity and profitability variabels had no positive on tax aggressiveness, while the leverage and liquidity variabels have a positive and significant effect on tax aggressiveness.
\end{abstract}

Keywords: Tax Aggressiveness; Capital Intensity; Leverage; Liquidity; Profitability

\section{PENDAHULUAN}

Pajak berdasarkan Undang-Undang Nomor 16 Tahun 2009 ialah kontribusi wajib kepada negara yang terutang oleh orang pribadi maupun badan yang bersifat memaksa, dengan tidak memperoleh imbalan secara langsung serta digunakan untuk keperluan negara bagi sebesar-besarnya kemakmuran rakyat. Menurut Mardiasmo (2019), pembayaran pajak merupakan suatu bentuk perwujudan kewajiban kenegaraan dan peran Wajib Pajak dalam melaksanakan kewajiban perpajakannya untuk pembiayaan Negara dan pembangunan nasional. Perpajakan adalah sumber paling potensial dari pendapatan negara yang menduduki persentase tertinggi dalam Anggaran Pendapatan dan Belanja Negara (APBN) jika dibandingkan dengan pendapatan lainnya. Peranan pajak sangat penting dalam kehidupan negara, karena tanpa adanya pajak aktivitas negara akan sulit dilaksanakan. Pemerintah menggunakan pajak untuk membiayai segala kepentingan baik yang ada di tingkat pusat maupun daerah. Adanya suatu kepentingan yang berbeda antara pemerintah dan wajib pajak, perbedaan kepentingan yang dimaksud adalah wajib pajak akan mencoba membayarkan pajak mereka serendah mungkin karena hal tersebut akan mengurangi jumlah keuntungan yang diperoleh.Sementara pemerintah membutuhkan dana untuk membiayai semua kegiatan kenegaraan yang sebagian besar kegiatannya dibiayai oleh pajak. Karena adanya perbedaan kepentingan tersebut, maka wajib pajak akan berusaha melakukan tindakan agresivitas pajak supaya beban pajak yang ditanggung perusahaan dapat ditekan serendah-rendahnya (Suandy, 2016).

Definisi agresivitas pajak menurut Frank, Lynch, \& Rego (2009), merupakan kegiatan memanipulasi pendapatan kena pajak yang dibuat melalui kegiatan perencanaan pajak dengan cara legal (Tax Avoidance) maupun ilegal (Tax Evation). Perusahaan akan dianggap semakin agresif terhadap pajak apabila jumlah penghematan pajak yang dilakukan perusahaan semakin tinggi. Terdapat beberapa faktor yang mempengaruhi agresivitas pajak, antara lain: intensitas modal, leverage, likuiditas, dan profitabilitas.

Intensitas modal adalah perusahaan yang menyimpan investasinya dalam bentuk aset tetap. Semakin banyak aset tetap yang diinvestasikan oleh perusahaan maka perusahaan dianggap semakin agresif terhadap pajak. Hal tersebut dikarenakan umur ekonomis yang terdapat pada aset tetap bisa memunculkan suatu beban depresiasi di setiap tahunnya. Beban depresiasi tersebut akan menjadi unsur penambah pada beban perusahaan dan menjadi unsur pengurang terhadap laba yang dihasilkan perusahaan. Apabila jumlah laba yang diperoleh perusahaan berkurang, maka akan berimbas pada beban pajak perusahaan menjadi rendah, sehingga 
jumlah kas perusahaan untuk membayar pajak juga akan ikut rendah. Penelitian (Raflis \& Ananda, 2020; Ayem \& Setyadi, 2019, dan Hidayat \& Fitria, 2018) memberikan bukti bahwa variabel intensitas modal memiliki pengaruh yang positif pada agresivitas pajak, sedangkan penelitian Dande (2018) dan Liani \& Saifudin (2020), memberikan bukti bahwa variabel intensitas modal memiliki pengaruh yang negatif pada agresivitas pajak.

Variabel selanjutnya Leverage ialah rasio yang menunjukkan jumlah modal eksternal yang dipakai perusahaan dalam menjalankan kegiatan operasinya (Liani, 2020). Perusahaan yang mempunyai sumber dana pinjaman atau utang yang tinggi, hal ini berarti perusahaan juga akan membayar biaya bunga yang tinggi kepada kreditur. Tinggi rendahnya suatu leverage perusahaan juga akan berpengaruh terhadap tinggi rendahnya jumlah pajak yang dibayarkan. Hal ini disebabkan karena biaya bunga yang ditimbulkan dari utang dapat menjadi unsur pengurang dalam penghitungan pajak, sehingga hal tersebut akan berimbas pada jumlah pajak yang dibayarkan menjadi lebih rendah. Pada penelitian (Fitriyani, 2020; Muliawati \& Karyada, 2020 dan Hidayat \& Fitria, 2018) memberikan bukti bahwa variabel leverage memiliki pengaruh yang positif pada agresivitas pajak, sedangkan penelitian Maulana (2020) dan Sulistyowati \& Ulfah (2018), memberikan bukti bahwa variabel leverage memiliki pengaruh yang negatif pada agresivitas pajak.

Likuiditas ialah kemampuan suatu entitas bisnis dalam membayar kewajiban lancar yang jatuh tempo pada waktu dekat serta kemampuan entitas bisnis dalam menangani situasi mendesak yang memerlukan dana (Kieso, Weygandt, dan Warfield, 2018). Pada penelitian (Gusharita, 2020; Ramadani \& Hartiyah, 2020 dan Indradi 2018) memberikan bukti bahwa variabel likuiditas mempunyai pen garuh yang positif pada agresivitas pajak, sedangkan penelitian Muliasari \& Hidayat (2020) memberikan bukti bahwa variabel likuiditas mempunyai pengaruh yang negatif pada agresivitas pajak

Menurut penelitian Maulana (2020), Ayem (2019), dan Sulistyowati \& Ulfah (2018) menyatakan bahwa profitabilitas memiliki pengaruh yang positif pada agresivitas pajak, sedangkan penelitian Fitriyani (2020) dan Dande (2018), memberikan bukti bahwa variabel profitabilitas mempunyai pengaruh yang negatif pada agresivitas pajak.

Alasan peneliti meneliti tentang Agresivitas Pajak ialah karena masih banyak terjadi praktik penghindaran pajak (tax avoidance) dan penggelapan pajak (tax evation) yang mempengaruhi pendapatan negara. Dilansir oleh www.gresnews.com bahwa PT.Indofood Sukses Makmur Tbk telah melakukan penghindaran pajak pada tahun 2015. Perkara pajak tersebut berkaitan dengan penghindaran pajak senilai 1,3 miliar, pokok perkara ini bermula ketika PT.Indofood Sukses Makmur Tbk melakukan pemekaran usaha dengan cara mendirikan perusahaan baru dan mengalihkan aktiva, pasiva dan operasional Divisi Noodle (Pabrik mie instan) kepada PT.Indofood CBP Sukses Makmur. Pemekaran yang dilakukan oleh PT Indofood Sukses Makmur Tbk ini dilakukan untuk menghindari pajak, namun dengan pemekaran usaha Direktorat Jenderal Pajak tetap memberikan keputusan bahwa PT Indofood Sukses Makmur Tbk harus tetap membayar pajak yang terutang tersebut senilai 1,3 miliar. Selain itu, tingkat perkembangan perusahaan manufaktur sub sektor food and beverage ini juga sangat pesat, hal ini bisa dibuktikan dengan semakin bertambahnya jumlah perusahaan manufaktur sub sektor food and beverage yang terdaftar di BEI setiap tahunnya. Perusahaan manufaktur sub sektor food and beverage juga selalu mendapatkan perhatian para investor dikarenakan perusahaan ini dianggap tidak ada matinya karena jenis produk yang dihasilkan perusahaan tersebut merupakan produk yang akan selalu dibutuhkan oleh konsumen

\section{METODE}

Penelitian ini merupakan penelitian kuantitatif. Objek penelitian pada penelitian ini adalah Perusahaan Manufaktur sub sektor food and beverage yang terdaftar di Bursa Efek Indonesia (BEI) periode tahun 2015-2019. Jumlah populasi dalam penelitian ini adalah 26 perusahaan dan didapatkan sampel sebesar 13 perusahaan dengan teknik pengambilan sampel purposive sampling. Adapun kriteria dalam pengambilan sampel pada penelitian ini yaitu 1) Perusahaan Manufaktur sub sektor food and beverage yang telah terdaftar di BEI tahun 2015-2019. 2) Perusahaan Manufaktur sub sektor food and beverage yang mempublikasikan laporan keuangan yang telah di audit dan menyampaikan data secara lengkap yang berhubungan dengan variabel yang diteliti selama periode penelitian. 3) Perusahaan Manufakatur sub sektor food and beverage yang tidak mengalami kerugian selama periode 2015-2019. Berikut uraian dari variable dalam penelitian:

\section{Agresivitas Pajak}

Dalam mengukur agresivitas pajak, peneliti menggunakan metode Cash Effective Tax Rate (CETR). CETR dipilih karena diharapkan dapat mengetahui keagresifan perencanaan pajak yang dilakukan suatu perusahaan baik melalui perbedaan permanen maupun perbedaan temporer, serta CETR ini mampu melihat secara langsung besar kecilnya jumlah kas perusahaan yang dibayarkan untuk pajak (Suyanto \& Supramono, 2012). Secara operasional semakin tinggi nilai CETR akan menggambarkan semakin rendahnya tingkat agresivitas pajak perusahaan, begitu juga sebaliknya semakin rendah nilai CETR maka hal tersebut menggambarkan semakin tingginya tingkat agresivitas pajak (Judi Budiman dan Setiyono, 2012). 
$C E R T=\frac{\text { Pembayaran Pajak }}{\text { Pendapatan Sebelum Pajak }}$

Keterangan:

CETR: Cash Effetive Tax Rate perusahaan i pada periode $\mathrm{t}$

Pembayaran Pajak: Jumlah pajak yang dibayarkan perusahaan i pada periode ke $\mathrm{t}$

Pendapatan Sebelum Pajak: Pendapatan sebelum kena pajak perusahaan i pada periode ke $t$

\section{Intensitas Modal}

Intensitas modal diukur dengan membandingkan antara total aset tetap bersih dengan total aset yang dimiliki perusahaan. Pengukuran intensitas modal pada penelitian ini mengacu pada penelitian (Hidayat \& Fitria, 2018) yaitu:

$I M=\frac{\text { Total Aset Tetap Bersih }}{\text { Total Aset }}$

\section{Leverage}

Leverage dalam penelitian ini dihitung dengan menggunakan DAR (Debt to Asset Ratio). DAR adalah rasio yang digunakan perusahaan untuk membandingan antara total utang dengan total aset. Menurut Kasmir (2012) DAR diperoleh dengan rumus sebagai berikut:

$D A R=\frac{\text { Total Utang }}{\text { Total Aset }}$

\section{Likuiditas}

Likuiditas pada penelitian ini dihitung dengan menggunakan rasio cepat (quick ratio). Menurut Kasmir (2012) likuiditas diukur dengan rumus sebagai berikut:

Rasio Cepat $=\frac{\text { Aset Lancar }- \text { Persediaan }}{\text { Kewajiban Lancar }}$

\section{Profitabilitas}

Profitabilitas dalam penelitian ini diukur dengan menggunakan proksi Return On Asset (ROA). Menurut Rodriguez dan Arias (2012) ROA dapat dihitung dengan membandingkan laba bersih setelah pajak dibagi dengan total aset.

$$
R O A=\frac{\text { Laba Bersih setelah Pajak }}{\text { Total Aset }}
$$

\section{Analisis Regresi Data Panel}

Data panel (pool date) merupakan gabungan dari data runtut waktu (time series) dan data silang (cross section). Data time series ialah data yang dapat dikumpulkan dari waktu ke waktu pada satu objek. Sementara data cross section ialah data yang dapat dikumpulkan dari beberapa objek pada satu waktu. Jadi, data panel merupakan data yang dikumpulkan dari beberapa objek dengan beberapa waktu (Basuki dan
Prawoto, 2017). Rumus untuk menguji regresi data panel adalah sebagai berikut:

CETR $_{i t}=\alpha+b_{1} I M_{i t}+b_{2} D A R_{i t}+b_{3} Q R_{i t}+b_{4} R O A_{i t}+e$

Keterangan:

CETR : Agresivitas Pajak (CETR)

a : Konstanta

$b_{n}:$ Koefisien Regresi

IM : Intensitas Modal

DAR : Leverage

QR : Likuiditas

ROA : Profitabilitas

i : Unit Cross Section

$\mathrm{t}$ : Periode Waktu (time series)

e : error

\section{HASIL DAN PEMBAHASAN}

Dalam penelitian ini mengunakan pendekatan data panel. Berikut output regresi Random Effect Model yang sudah melalui pemilihan model dari regresi data panel yang terbaik. Selanjutnya dapat dibuat ringkasan hasil seperti terlihat pada tabel di bawah ini;

Tabel 1.Ringkasan Hasil Analisis Regresi Data Panel Random

\begin{tabular}{clcccc}
\multicolumn{5}{c}{ Effect Model } \\
\hline No & \multicolumn{1}{c}{ Variabel Bebas } & $\begin{array}{c}\text { Koefisien } \\
\text { Regresi }\end{array}$ & $\begin{array}{c}\text { t- } \\
\text { hitung }\end{array}$ & T-tabel & $\begin{array}{c}p- \\
\text { value }\end{array}$ \\
\hline 1 & Intensitas Modal (X1) & $-0,219$ & $-1,276$ & $-1,671$ & 0,207 \\
2 & Leverage (X2) & $-0,142$ & $-2,301$ & $-1,671$ & 0,025 \\
3 & Likuiditas (X3) & $-0,192$ & $-2,343$ & $-1,671$ & 0,022 \\
4 & Profitabilitas (X4) & $-0,056$ & $-1,169$ & $-1,671$ & 0,247 \\
\hline \multicolumn{6}{c}{ Konstanta $=-1.882$} \\
Adjusted R Square $=0.167$ & & & \\
& Fhitung $=4.204$ \\
F tabe1 = 2.43
\end{tabular}

Sumber: hasil olahan Eviews-9

Berdasarkan uji bersama-sama atau Uji $\mathrm{F}$ menunjukkan bahwa nilai $\mathrm{F}$ hitung $(4,204)$ lebih besar daripada $F$ tabel $(2,43)$. Dengan demikian, dapat disimpulkan bahwa, intensitas modal, leverage, likuiditas dan profitabilitas secara bersama-sama berpengaruh terhadap agresivitas pajak pada pada perusahaan manufaktur sub sektor food and beverage yang terdaftar di Bursa Efek Indonesia tahun 2015-2019. untuk pengujian secara indivudu atau $\mathrm{Uji} t$ dapat dijelaskan di bawah ini.

\section{Pengaruh Intensitas Modal terhadap Agresivitas Pajak}

Intensitas modal memiliki nilai koefisien $-0,219$ dan nilai $t$ hitung $(-1,276)$ lebih kecil dari $t$ tabel (1,671). Dengan demikian, dapat disimpulkan bahwa intesitas modal tidak berpengaruh terhadap agresivitas pajak. Hubungan tersebut mengindikasikan bahwa semakin tinggi profitabilitas suatu perusahaan tidak selalu diikuti dengan rendahnya CETR. Penelitian ini menunjukkan bahwa variabel intensitas modal tidak berpengaruh positif terhadap agresivitas pajak, karena semua sampel dalam penelitian ini menggunakan metode 
penyusutan garis lurus dalam menyusutkan aset tetapnya, sehingga tidak menimbulkan penghematan yang signifikan terhadap jumlah pajak yang dibayarkan perusahaan, lain halnya jika perusahaan menggunakan metode penyusutan saldo menurun atau yang disebut juga dengan metode penyusutan yang dipercepat sehingga penyusutan yang dihasikan besar dan jumlah kas yang dibayarkan perusahaan juga akan lebih kecill. Penelitian ini sejalan dengan penelitian yang dilakukan oleh (Cahyadi, Surya, Wijaya \& Salim, 2020; Ambarita, Pakpahan \& Sidharta, 2017 dan Indradi 2018) yang juga menemukan bukti bahwa intensitas modal tidak berpengaruh signifikan terhadap agresivitas pajak.

\section{Pengaruh Leverage terhadap Agresivitas Pajak}

Leverage memiliki nilai koefisien -0.142 dan nilai t hitung $(-2,301)$ lebih kecil dari t tabel $(-1,671)$. Dengan demikian dapat disimpulkan bahwa leverage berpengaruh terhadap agresivitas pajak. Hubungan tersebut memberikan bukti bahwa semakin tinggi leverage maka akan selalu di ikuti dengan semakin rendahnya CETR atau semakin tinggi tingkat agresivitas pajaknya pada perusahaan manufaktur sub sektor food and beverage. Hal ini disebabkan karena semakin tinggi nilai leverage suatu perusahaan, berarti akan semakin tinggi utang dan semakin tinggi pula biaya bunga yang timbul dari utang tersebut. Bunga dalam peraturan perpajakan Pasal 6 Ayat 1 huruf a angka 3 UU No.36 Tahun 2008 merupakan biaya yang boleh dikurangkan terhadap penghasilan kena pajak, sehingga hal ini akan berpengaruh terhadap jumlah pajak yang dibayarkan suatu perusahaan. Jadi, semakin tinggi utang suatu perusahaan maka nilai CETR akan semakin rendah. Hasil penelitian ini sejalan dengan penelitian yang dilakukan oleh (Cahyadi dkk, 2020; Muliasari \& Hidayat, 2020; Muliawati \& Karyada, 2020; Liani, 2020; Fitriyani, 2020 dan Hidayat \& Fitria, 2018) yang juga menemukan bukti bahwa leverage berpengaruh negatif signifikan terhadap agresivitas pajak.

\section{Pengaruh Likuiditas terhadap Agresivitas Pajak}

Likuiditas memiliki nilai koefisien -0,192 dan nilai $\mathrm{t}$ hitung $(-2,343)$ lebih kecil dari t tabel $(-1,671)$ dengan demikian dapat disimpulkan bahwa likuiditas berpengaruh terhadap agresivitas pajak. Hubungan tersebut memberikan bukti bahwa semakin tinggi likuiditas maka akan semakin tinggi tingkat agresivitas pajaknya. Penelitian ini menunjukkan bahwa variabel likuiditas berpengaruh positif signifikan terhadap agresivitas pajak. Hal ini disebabkan karena perusahaan cenderung mengurangi pendapatan yang dimiliki dengan menambah jumlah utang sehingga menggunakan sebagian pendapatannya untuk membayar bunga. Perusahaan cenderung menggunakan utang jangka pendek agar mengurangi jumlah pajak yang dibayarkan. Jadi semakin tinggi likuiditas suatu perusahaan maka nilai CETR akan semakin rendah. Hasil penelitian ini sejalan dengan penelitian yang dilakukan oleh
(Ramadani \& Hartiyah, 2020; Gusharita, 2020; Indradi, 2018) dan Yuliana, 2018) yang juga menemukan bukti bahwa likuiditas berpengaruh positif signifikan terhadap agresivitas pajak.

\section{Pengaruh Profitabilits terhadap Agresivitas Pajak}

Profitabilitas memiliki nilai koefisien -0,056 dan nilai $\mathrm{t}$ hitung $(-1,169)$ lebih besar dari $\mathrm{t}$ tabel $(-1,671)$ dengan demikian dapat disimpulkan bahwa variabel profitabilitas tidak berpengaruh terhadap agresivitas pajak. Hubungan tersebut mengindikasikan bahwa semakin tinggi profitabilitas suatu perusahaan tidak selalu diikuti dengan rendahnya CETR atau semakin tinggi agresivitas pajak. Penelitian ini mengindikasikan bahwa tinggi rendahnya laba yang diperoleh perusahaan tidak dapat menjadi acuan bahwa perusahaan yang memperoleh laba tinggi akan melakukan tindakan agresivitas pajak yang tinggi pula. Seperti contoh pada PT Ultra Jaya Milk Industry \& Trading Company Tbk yang memiliki laba tinggi (nilai ROA berada diatas ratarata perusahaan manufaktur sub sektor food and beverage) dan PT ULTJ ini tetap membayar pajak sesuai dengan peraturan $(>25 \%)$. Hasil penelitian ini sejalan dengan penelitian yang dilakukan oleh (Putri, 2020; Azam \& Subekti, 2020; Dharmayanti, 2018; Mustika, 2017; Nugraha \& Meiranto, 2015 dan Ardyansyah \& Zulaikha, 2014) yang juga menemukan bukti bahwa profitabilitas tidak berpengaruh signifikan terhadap agresivitas pajak.

\section{SIMPULAN}

Berdasarkan hasil penelitian dan pembahasan mengenai pengaruh intensitas modal, leverage, likuiditas dan profitabilitas terhadap agresivitas pajak yang diproksikan dengan CETR, maka dapat disimpulkan bahwa intensitas modal dan profitabilitas tidak berpengaruh positif terhadap agresivitas pajak, sedangkan leverage dan likuiditas berpengaruh positif dan signifikan terhadap agresivitas pajak.

\section{DAFTAR PUSTAKA}

Ambarita, S., Pakpahan, J., \& Sidharta, J. (2017). Pengaruh Corporate Social Responsibility Dan Capital Intensity Terhadap Agresivitas Pajak Pada Perusahaan Pertambangan Yang Terdaftar Di Bursa Efek

Indonesia Periode Tahun 2011 - 2015. Fundamental Management Journal, 2(2), 65-72

Ardyansyah, Danis dan Zulaikha, 2014. Pengaruh Size,Leverage, Profitability,Capital Intensity Ratio dan Komisaris Independen Terhadap Effective Tax Rate (ETR). Diponegoro Journal Of Accounting, Vol. 3,No. 2, 1-9.

Ayem, Sri., \& Setyadi, Afik. (2019). Pengaruh Profitabilitas, Ukuran Perusahaan, Komite Audit dan Capital Intensity Terhadap Agresivitas Pajak. Jurnal Akuntansi Pajak Dewantara Vol.1 No.2, 228-241. 
Azam, A., \& Subekti, K, V. (2020). Pengaruh Profitabilitas dan Ukuran Perusahaan terhadap Agresivitas Pajak dengan Good Corporate Governance sebagai Variabel Moderating. Media Akutansi Perpajakan. Vol 5. No 2, Hal 1-10.

Basuki, Agus Tri., \& Prawoto, Nano. (2017). Analisis Regresi dalam Penelitian Ekonomi dan Bisnis Dilengkapi Aplikasi SPSS dan Eviews. Jakarta: Rajawali Pers.

Cahyadi, H., Surya, C., Wijaya, H., \& Salim, S. (2020). Pengaruh Likuiditas, Leverage,Intensitas Modal, dan Ukuran Perusahaan Terhadap Agresivitas Pajak. STATERA: Jurnal Akuntansi dan Keuangan, 2(1), 9-16

Dharmayanti,N. (2018). Pengaruh Likuiditas, Leverage dan Profitibilitas, terhadap Agresivitas Pajak (Studi Empiris pada perusahaan manufaktur yang termasuk dalam LQ45 Bursa Efek Indonesia (BEI) Periode 2013-2017. Simposium Nasional Multidisiplin Universitas Muhammadiyah Tangerang.

Dande, Natalia. Ursula. (2018). Analisis Pengaruh Karakteristik Perusahaan dan Corporate Social Responsibility Terhadap Agresivitas Pajak Pada Perusahaan Tambang. PARSIMONIA VOL.5.NO.1 APRIL 2018, 97-112.

Fitriyani, Muayyinah. Nurul. (2020). Pengaruh Ukuran Perusahaan, Profitabilitas, Likuiditas, Leverage, dan Intensitas Aset Tetap Terhadap Agresivitas Pajak

Frank, Mary. Margaret., Lynch , Luann. J., \& Rego, Sonja. Olhoft. (2009). Tax Reporting Aggressiveness and its Relation to Aggressive Financial Reporting. THE ACCOUNTING REVIEW, 467-496.

Gusharita, Ulpa. (2020). Pengaruh Likuiditas, Leverage, Komisaris Independen, Ukuran Perusahaan dan Koneksi Politik Terhadap Agresivitas Pajak di Perusahaan Sub Sektor Pertambangan Batu Bara yang Terdaftar di BEI. Skripsi dipublikasikan.

Hidayat, Agus. Taufik., \& Fitria, Eta. Febrina. (2018). Pengaruh Capital Intensity, Inventory Intensity, Profitabilitas dan Leverage Terhadap Agresivitas Pajak. EKSIS Vol.13 No.2, 157-168.

Indradi, Donny. (2018). Pengaruh Likuiditas, Capital Intensity Terhadap Agresivitas Pajak. Jurnal Akuntansi Berkelanjutan Indonesia Vol.1,No.1, 147-167

Kasmir. (2012). Analisis Laporan Keuangan. Jakarta: PT RajaGrafindo Persada

Kieso. Donald E., Jerry J. Weygandt, Terry D. Warfield (2018). Intermediate Accounting. IFRS Edition.Second Edition. United States : WILEY

Liani, Ayu. Vepri., \& Saifudin. (2020). Likuiditas, Leverage, Profitabilitas, Ukuran Perusahaan dan Capital Intensity : Implikasinya Terhadap Agresivitas Pajak. Majalah Ilmiah Solusi Vol.18, No.2, 101-120.
Mardiasmo. (2019). PERPAJAKAN EDISI 2019. jakarta: PENERBIT ANDI.

Maulana, Ilham. Ahmad. (2020). Faktor-Faktor Yang Mempengaruhi Agresivitas Pajak Pada Perusahaan Properti dan Real Estate. KRISNA : Kumpulan Riset Akuntansi Vol.11, No.2, 155-163.

Muliasari, Riri., \& Hidayat, Angga. (2020). Pengaruh Likuiditas, Leverage dan Komisaris Independen Terhadap Agresivitas Pajak Perusahaan. SULTANIST : Jurnal Manajemen dan Keuangan Vol.8 No.1 , 28-36.

Muliawati, I. Ayu., \& Karyada, I. Putu. (2020). Pengaruh Leverage dan Capital Intensity Terhadap Agresivitas Pajak dengan Komisaris Independen Sebagai Variabel Pemoderasi. Hita Akuntansi dan Keuangan Universitas Hindu Indonesia, 495-524

Mustika. M (2017). Pengaruh Corporate Social Responsibility, Ukuran Perusahaan, Profitabilitas, Leverage, Capital Intensity Dan Kepemilikan Keluarga Terhadap Agresivitas Pajak (Studi Empiris Pada Perusahaan Pertambangan Dan Pertanian Yang Terdaftar Di Bursa Efek Indonesia Periode Tahun 2012-2014). Jurnal Online Mahasiswa, 4(1), 1886-1990.

Nugraha N. B, and Meiranto, M. (2015). Pengaruh Corporate Social Responsibility, Ukuran Perusahaan, Profitabilitas, Leverage Dan Capital Intensity Terhadap Agresivitas Pajak (Studi Empiris pada Perusahaan Non Keuangan yang Terdaftar di Bursa Efek Indonesia 2012-2013)," Diponegoro Journal of Accounting, vol. 4, no. 4, pp. 564 - 577,

Putri. R, B T, W. (2020). Pengaruh Leverage, Profitabilitas dan Ukuran Perusahaan terhadap Agresivitas Pajak (Studi kasus Pada Perusahaan Manufaktur Sub Sektor Makanan dan Minuman yang terdaftar di Bursa Efek Indonesia Periode tahun 2016-2018). Thesis, STIE PGRI Dewantara.

Raflis, Ratnawati., \& Ananda, Dhea. Rizky. (2020). Dampak Corporate Governance Dalam Memoderasi Pengaruh Likuiditas, Leverage dan Capital Intensity Pada Agresivitas Pajak Perusahaan Pertambangan. Jurnal Ekonomi dan Bisnis Dharma Andalas Volume 22 No 1, Januari 2020, 120-133.

Ramadani, Dinda. Chairunissa., \& Hartiyah, Sri. (2020). Pengaruh Corporate Social Responsibility, Leverage, Likuiditas, Ukuran Perusahaan dan Komisaris Independen Terhadap Agresivitas Pajak. (JEBE) Journal of Economic, Business and Engineering Vol.1 No.2, 238-247.

Rodriguez, Elena. Fernandez., \& Arias, Antonio. Martinez. (2012). Do Business Characteristics Determine an Effective Tax Rate. The Chinese Economy Vol.45, No.6, 60-83. 
Sulistyowati, \& Ulfah, Lisa. Ariska. (2018). Pengaruh Pengungkapan Corporate Social Responsibility, Profitabilitas, dan Leverage Terhadap Agresivitas Pajak. BALANCE Vol.15 No.2, 237-253.

Suyanto, Krisnata. Dwi., \& Supramono. (2012). Likuiditas, Leverage, Komisaris Indpenden, dan Manajemen Laba Terhadap Agresivitas Pajak Perusahaan. Jurnal Keuangan dan Perbankan Vol.16, No.2, 167-177.

Yuliana, Ina. Fachrina., \& Wahyudi, Djoko. (2018). Likuiditas, Profitabilitas, Leverage, Ukuran Perusahaan, Capital Intensity dan Inventory Intensity Terhadap Agresivitas Pajak. Dinamika Akuntansi, Keuangan dan Perbankan Vol.1, No.7, 105-120. 